\title{
Patterns of mercury dispersion from local and regional emission sources, rural Central Wisconsin, USA
}

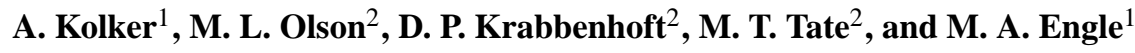 \\ ${ }^{1}$ US Geological Survey, Eastern Energy Resources Science Center, Reston, VA, 20192 USA \\ ${ }^{2}$ US Geological Survey, Wisconsin Water Science Center, Middleton, WI, 53562 USA
}

Received: 6 December 2009 - Published in Atmos. Chem. Phys. Discuss.: 21 January 2010

Revised: 23 April 2010 - Accepted: 26 April 2010 - Published: 17 May 2010

\begin{abstract}
Simultaneous real-time changes in mercury $(\mathrm{Hg})$ speciation- reactive gaseous $\mathrm{Hg}(\mathrm{RGM})$, elemental $\mathrm{Hg}\left(\mathrm{Hg}^{\circ}\right)$, and fine particulate $\mathrm{Hg}\left(\mathrm{Hg}-\mathrm{PM}_{2.5}\right)$, were determined from June to November, 2007, in ambient air at three locations in rural Central Wisconsin. Known $\mathrm{Hg}$ emission sources within the airshed of the monitoring sites include: 1) a 1114 megawatt (MW) coal-fired electric utility generating station; 2) a Hg-bed chlor-alkali plant; and 3) a smaller (465 MW) coal-burning electric utility. Monitoring sites, showing sporadic elevation of $\mathrm{Hg}^{\circ}, \mathrm{Hg}-\mathrm{PM}_{2.5}$, and RGM were positioned at distances of 25,50 and $100 \mathrm{~km}$ northward of the larger electric utility. Median concentrations of $\mathrm{Hg}^{\circ}, \mathrm{Hg}$ $\mathrm{PM}_{2.5}$, and RGM were $1.3-1.4 \mathrm{ng} \mathrm{m}^{-3}, 2.6-5.0 \mathrm{pg} \mathrm{m}^{-3}$, and $0.6-0.8 \mathrm{pg} \mathrm{m}^{-3}$, respectively. A series of RGM events were recorded at each site. The largest, on 23 September, occurred under prevailing southerly winds, with a maximum RGM value $\left(56.8 \mathrm{pg} \mathrm{m}^{-3}\right)$ measured at the $100 \mathrm{~km}$ site, and corresponding elevated $\mathrm{SO}_{2}(10.4 \mathrm{ppbv}$; measured at $50 \mathrm{~km}$ site). The finding that $\mathrm{RGM}, \mathrm{Hg}^{\circ}$, and $\mathrm{Hg}-\mathrm{PM}_{2.5}$ are not always highest at the $25 \mathrm{~km}$ site, closest to the large generating station, contradicts the idea that RGM decreases with distance from a large point source. This may be explained if: 1) the $100 \mathrm{~km}$ site was influenced by emissions from the chlor-alkali facility or by RGM from regional urban sources; 2) the emission stack height of the larger power plant promoted plume transport at an elevation where the $\mathrm{Hg}$ is carried over the closest site; or 3) RGM was being generated in the plume through oxidation of $\mathrm{Hg}^{\circ}$. Operational changes at each emitter since 2007 should reduce their Hg output, potentially allowing quantification of the environmental benefit in future studies.
\end{abstract}

Correspondence to: A. Kolker (akolker@usgs.gov)

\section{Introduction}

Atmospheric emissions, transport and deposition of mercury $(\mathrm{Hg})$ are key processes leading to the global mercury contamination problem (Wiener et al., 2003). Mercury emissions to the atmosphere arise from natural and anthropogenic sources, and by re-emission of previously deposited $\mathrm{Hg}$ (reviewed by Banic et al., 2005). Speciation of atmospheric mercury is influenced by a combination of local emission sources, generally contributing a greater proportion of reactive species, and global long range transport of long lived species such as $\mathrm{Hg}^{\circ}$. Among local sources, the location, type of emitter, and amount of $\mathrm{Hg}$ emitted may be characteristic in distinguishing their contribution to the mercury budget of a given area.

In the present study, we set up three receptor stations at different locations within a rural study area having no major anthropogenic $\mathrm{Hg}$ emission sources within $25 \mathrm{~km}$ or more. Using this three-receptor array, changes in mercury speciation were continuously monitored, ultimately showing the influence of three $\mathrm{Hg}$ emission sources located at the periphery of the study area in opposing directions (Fig. 1), as well as regional sources from major urban areas of the US Midwest. The goals of the study were to: 1) distinguish multiple $\mathrm{Hg}$ inputs in a rural setting with relatively few $\mathrm{Hg}$ sources, that are directionally distinct; 2) track possible conversion between atmospheric $\mathrm{Hg}$ species; and 3) test the efficacy of simultaneous deployment of mercury speciation monitoring stations for possible use by the National Atmospheric Deposition Program (NADP) Atmospheric Mercury Network (AMNet).

\subsection{Study area}

The study area is predominantly agricultural with no major topographic barriers or resulting orographic effects between the sampling sites. The sampling sites are positioned at the

Published by Copernicus Publications on behalf of the European Geosciences Union. 


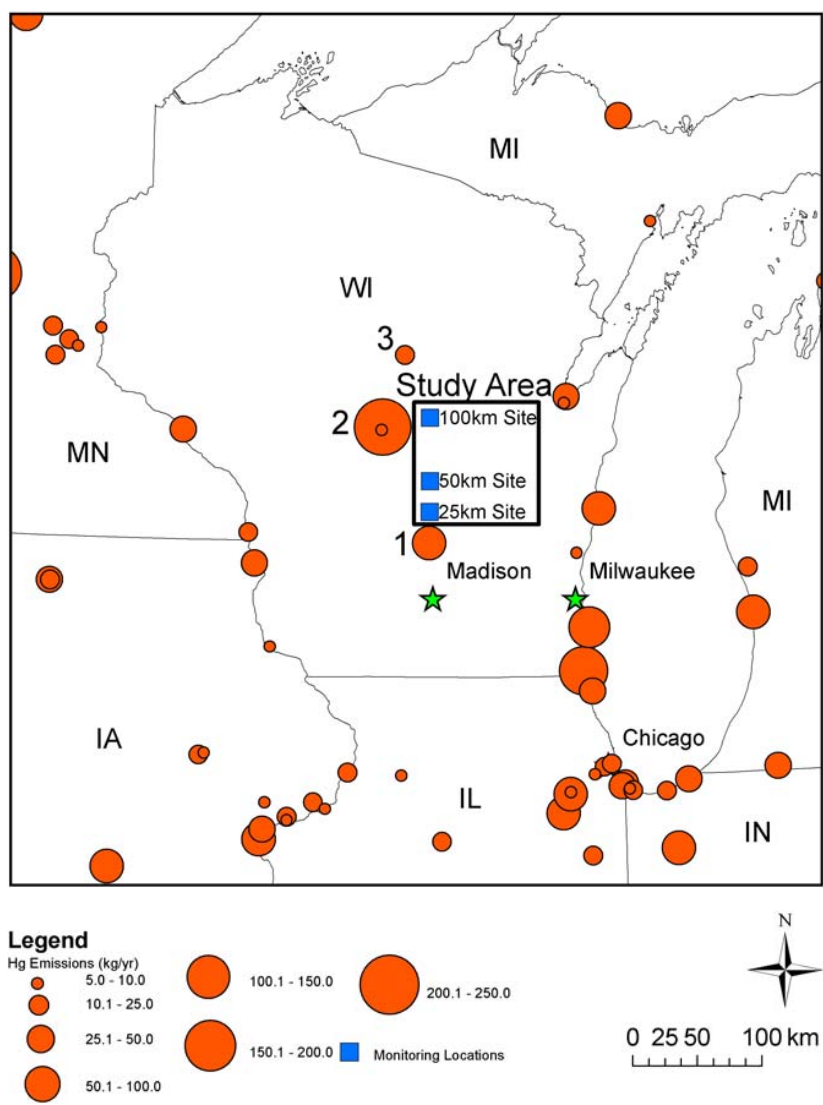

Fig. 1. Map of Wisconsin and adjoining States showing distribution of mercury emitters as of 2006, from EPA Toxics Release Inventory (EPA, 2008). Three emitters adjoin the study area: 1) $1114 \mathrm{MW}$ coal-burning utility power station; 2) mercury-bed process chloralkali facility; and 3) $465 \mathrm{MW}$ coal-burning utility power station. Mercury emitters contributing $5.0 \mathrm{~kg} / \mathrm{yr}$ or less are not shown.

easternmost margin of the Central Wisconsin Sand Plains physiographic province, an area of low relief comprising the basin of Glacial Lake Wisconsin, or in adjacent low-relief outwash areas to the east (e.g. Hooyer, 2001). From the $50 \mathrm{~km}$ site, $\mathrm{Hg}$ emission sources closest to the study area are located to the south, to the northwest, and to the northnorthwest, potentially making it possible to delineate their input on the basis of local wind patterns. The orientation of the sampling array was coincident with winds from the south, the most prevalent wind direction occurring during the summer and early fall in this part of Wisconsin, based on analysis of historic wind records. Field investigation spanned the period from June to November, 2007.

To track possible changes in mercury speciation associated with conversion between atmospheric $\mathrm{Hg}$ species during transport along a prevailing wind direction, Tekran speciation units were deployed at sampling sites with distances of 25,50 , and $100 \mathrm{~km}$ northward starting at one of the mercury sources, a combined $1114 \mathrm{MW}$ utility generating sta- tion burning Powder River Basin (PRB) coal. PRB coal is characteristically low in sulfur, and in mercury, with a mean $\mathrm{Hg}$ content of $0.08 \mathrm{ppm}$ for 612 samples in the USGS COALQUAL database (Bragg et al., 1998; Tewalt et al., 2001). Speciated measurements of atmospheric mercury in the immediate vicinity of the $1114 \mathrm{MW}$ generating station were not obtainable. In general, the portion of oxidized vs. elemental $\mathrm{Hg}$ released from coal fired power plants is highly variable and dependent on coal composition (especially $\mathrm{S}$ and halogen content), the presence/absence of specific emission control units, and general operating conditions of the plant (Kolker et al., 2006). Preceding this study, surveys in the vicinity of the chlor-alkali facility, located about $35 \mathrm{~km}$ WSW of the $100 \mathrm{~km}$ site showed very high levels of $\mathrm{Hg}^{\circ}$, and importantly, also a fraction of RGM.

Following completion of field measurements in 2007, significant operational changes were made to the three mercury emission sources adjoining the study area. In 2008, a new $525 \mathrm{MW}$ generating unit burning PRB coal was added to the $465 \mathrm{MW}$ multi-unit coal-fired electric utility located about $50 \mathrm{~km}$ NNW of the $100 \mathrm{~km}$ site (Peltier, 2008). Modifications to the existing $465 \mathrm{MW}$ capacity are also underway to upgrade its emissions controls (Electric Energy Online, 2009). The new $525 \mathrm{MW}$ unit is equipped with an activated carbon injection system to control mercury emissions and stateof the-art controls for $\mathrm{NO}_{\mathrm{x}}, \mathrm{SO}_{2}$, and particulate emissions (Campbell et al., 2009). At the chlor-alkali plant, conversion to mercury-free membrane technology is underway as part of an expansion of this facility (Hawthorne, 2007). Finally, at the $1114 \mathrm{MW}$ utility at the southernmost end of the study area, equipment and operational modifications to reduce emissions of $\mathrm{NO}_{\mathrm{x}}, \mathrm{SO}_{2}$ and $\mathrm{Hg}$ have been put in place or are planned. These changes make it impossible to replicate the local source conditions observed during the study, but source conditions similar to those sampled existed in the study area for an extended period up to and including 2007. With these changes, the contribution of local sources to transient atmospheric mercury levels in the study area should be reduced and future studies should allow for quantification of their environmental benefit.

\subsection{Sampling methods}

The USGS Mobile Atmospheric Mercury Laboratory (Mobile Lab; Kolker et al., 2007) was deployed at the $50 \mathrm{~km}$ site from June to November, 2007. The Mobile Lab utilizes a Tekran 1130/1135 mercury speciation unit coupled to a Tekran 2537A (serial \#219) cold vapor atomic fluorescence spectrometer (CVAFS; hereafter, "speciation system" for both Tekran instruments combined). The Mobile Lab speciation system was one of three fixed speciation systems deployed concurrently. Other fixed Tekran speciation systems were deployed at the $25 \mathrm{~km}$ site (\#236) and the $100 \mathrm{~km}$ site (\#173). A 4th speciation system (\#153) was alternated, first deployed in tandem with the Mobile Lab at the $50 \mathrm{~km}$ site 
(8 August to 25 September), then moved to the $100 \mathrm{~km}$ site (27 September to 22 November) for replicate measurements. In addition to its mercury speciation capability, the Mobile Lab has sampling and measurement capabilities for $\mathrm{NO}_{\mathrm{x}}$, $\mathrm{SO}_{2}$, ozone, $\mathrm{PM}_{2.5}$ mass, and meteorological parameters that can be used in conjunction with mercury speciation results. Portable meteorological stations were deployed at the $25 \mathrm{~km}$ and $100 \mathrm{~km}$ sites.

In addition to continuous monitoring of mercury speciation over a 6-month period, more intensive sampling of particulate matter (PM) was conducted over a 10-d period in July/August, 2007. During this period, low volume USGSdesign $\mathrm{PM}_{2.5}\left(16.7 \mathrm{~L} \mathrm{~min}^{-1}\right)$ or total suspended particulate (TSP; 30 $\mathrm{L} \mathrm{min}^{-1}$ ) samplers (Kolker et al., 2008) were deployed at each of the three mercury speciation sites $(25,50$, and $100 \mathrm{~km}$ ). Additionally, at the $50 \mathrm{~km}$ site a commercialdesign high volume (1500 $\mathrm{L} \mathrm{min}^{-1}$ ) TSP sampler (Tisch Environmental TE-5000) was used concurrently with the low volume sampler for the same period. Using the low volume samplers, total particulate $\mathrm{Hg}$ (Hg-TSP), or $\mathrm{Hg}-\mathrm{PM}_{2.5}$, were collected on pre-fired $47 \mathrm{~mm}$ quartz fiber filters. Using the high volume TSP, aerosols were collected on pre-fired $20 \times 25 \mathrm{~cm}$ quartz fiber filters. For each dedicated PM sampler, the sampling orifice was mounted at a height of $2 \mathrm{~m}$.

\subsection{Analysis methods}

Atmospheric $\mathrm{Hg}$ speciation systems deployed within the Mobile Lab and at the other two sampling sites $(25 \mathrm{~km}$ and $100 \mathrm{~km}$ ) utilize a Tekran 1130/1135 speciation unit coupled to a Tekran 2537A CVAFS. The system has been described elsewhere in greater detail (e.g. Landis et al., 2002; Engle et al., 2008; Kolker et al., 2008; and references therein). To determine $\mathrm{Hg}$ speciation, RGM is sequentially collected on a $\mathrm{KCl}$-coated annular denuder, fine particulate $\mathrm{Hg}-\mathrm{PM}_{2.5}$ is collected on a re-generable particulate filter and $\mathrm{Hg}^{\circ}$ is collected on gold traps. The three mercury species collected are thermally desorbed and analyzed by the Tekran 2537A as $\mathrm{Hg}^{\circ}$. Every $2 \mathrm{~h}$ the atmospheric $\mathrm{Hg}$ speciation system provides 12 consecutive 5-min average $\mathrm{Hg}^{\circ}$ concentrations and 1-h integrated $\mathrm{Hg}-\mathrm{PM}_{2.5}$ and RGM concentrations. The instruments were calibrated daily by an internal $\mathrm{Hg}^{\circ}$ permeation source. The $\mathrm{Hg}^{\circ}$ permeation sources were certified monthly. Pre-spiked denuders containing $48.4 \mathrm{pg}$ RGM (Frontier Geosciences) were analyzed by the speciation units to demonstrate both the accuracy and precision of the instruments (recovery $=98.6 \pm 13.1 \%, n=28$ ). The atmospheric $\mathrm{Hg}$ speciation system has an $\mathrm{Hg}^{\circ}$ detection limit of approximately $0.1 \mathrm{ng} \mathrm{m}^{-3}$ ( $0.5 \mathrm{pg}$ in absolute mass units). Minimum detection limits for RGM and $\mathrm{Hg}-\mathrm{PM}_{2.5}$ varied among instruments and sites but were generally $<2.0 \mathrm{pg} \mathrm{m}^{-3}(<1.2 \mathrm{pg}$ in absolute mass units). To determine the variability of the four speciation systems used in this study, tests were conducted whereby the units were attached to a single highvolume unheated manifold and exposed to ambient air, $\mathrm{Hg}^{\circ}$ - spiked ambient air, and RGM-spiked ambient air. Runs were made on the manifold system between April 2007 and November 2008, totaling more than 19 days of operation. Results from the April 2007 manifold study, conducted prior to the measurement period for this study, showed that the average percent relative standard deviation (\%RSD) between the four instruments was $5.9 \%$ for $\mathrm{Hg}^{\circ}$ (mean concentration $=10.9 \mathrm{ng} \mathrm{m}^{-3}$ ), $34.2 \%$ for RGM (mean concentration $=2.6 \mathrm{pg} \mathrm{m}^{-3}$ ), and $8.3 \%$ for $\mathrm{Hg}-\mathrm{PM}_{2.5}$ (mean concentration $=5.8 \mathrm{pg} \mathrm{m}^{-3}$ ). Testing during November 2008, demonstrated that \% RSD values for RGM and $\mathrm{Hg}-\mathrm{PM}_{2.5}$ decreased dramatically during exposure to higher concentrations. For example, \%RSD for RGM concentrations $<10 \mathrm{pg} \mathrm{m}^{-3}$ was $14.2 \%$ but improved to $9.8 \%$ at $>10 \mathrm{pg} \mathrm{m}^{-3}$.

Exposed quartz fiber filters and filter blanks were analyzed by CVAFS according to methods modified from Olund et al. (2004) for particulate mercury in water samples. Filters are digested in PTFE bombs in a $5 \% \mathrm{BrCl}$ solution, at $50^{\circ} \mathrm{C}$ for 5 days, to insure complete oxidation of particle-bound $\mathrm{Hg}$ to soluble forms. Sample digestion and analysis were carried out at the USGS Wisconsin Water Science Center Mercury Laboratory, in Middleton, Wisconsin, using an automated flow injection system in which a CVAFS system is incorporated (Olund et al., 2004). A detection limit of $18 \mathrm{pg}$ was attained for filter extracts based on analysis of 7 field blanks, corresponding to $\sim 0.71 \mathrm{pg} \mathrm{m}^{-3}$ for $\mathrm{Hg}-\mathrm{PM}_{2.5}$ in air.

\section{Results and discussion}

\subsection{Mercury speciation}

Near continuous monitors of mercury speciation were obtained at the 25, 50, and $100 \mathrm{~km}$ sites from June through November of 2007. Summary results for RGM, $\mathrm{Hg}^{\circ}$ and $\mathrm{Hg}-$ $\mathrm{PM}_{2.5}$ are shown in Fig. 2 and Table 1. Baseline RGM levels are generally less than $3 \mathrm{pg} \mathrm{m}^{-3}$, with short term excursions approaching or exceeding $30 \mathrm{pg} \mathrm{m}^{-3}$ (e.g. on 23 September). For $\mathrm{Hg}^{\circ}$, baseline concentrations are less than $2 \mathrm{ng} \mathrm{m}^{-3}$ with excursions approaching or exceeding $5 \mathrm{ng} \mathrm{m}^{-3}$ (e.g. on 12 November).

Results given in Fig. 2 include unqualified speciation data, shown as solid lines, and speciation results that have been flagged for one or more quality assurance (QA) concerns, shown as lighter-colored equivalents. QA flags include an incomplete sampling cycle (less than $1 \mathrm{~h}$ of sampling), $\mathrm{Hg}^{\circ}$ measurements taken during the hour that manual $\mathrm{Hg}^{\circ}$ injection occurred, baseline voltage or baseline deviation problems, etc. Results are omitted for first two $\mathrm{Hg}^{\circ}$ measurements of the $\mathrm{Hg}^{\circ}$ cycle, during $\mathrm{Hg}^{\circ}$ manual air injections, and in all other cases where $\mathrm{Hg}^{\circ}$ data are questionable or the speciation system is not functioning properly. Where speciation system unit \#153 is used to duplicate the output of fixed unit \#219 at the $50 \mathrm{~km}$ site (8 August to 25 September) and \#173 at the $100 \mathrm{~km}$ site (27 September to 22 November) the replicates show good agreement (Fig. 2). 
Table 1. Summary statistics of $\mathrm{Hg}$ species concentrations for fixed Tekran measurements at the $25 \mathrm{~km}, 50 \mathrm{~km}$, and $100 \mathrm{~km}$ sites. Median and psuedo $\sigma$ (interquartile range/1.349) estimated using Kaplan-Meier survival curves for $\mathrm{Hg}^{\circ}$ data (values in ng $\mathrm{m}^{-3}$ ) and regression on order statistics (ROS) for the other species (values in $\mathrm{pg} \mathrm{m}^{-3}$ ), to account for measurements below method detection limits.

\begin{tabular}{lrrrrrrrrr}
\hline & $25 \mathrm{~km}$ & $50 \mathrm{~km}$ & $100 \mathrm{~km}$ & $25 \mathrm{~km}$ & $50 \mathrm{~km}$ & $100 \mathrm{~km}$ & $\begin{array}{r}25 \mathrm{~km} \\
\mathrm{Hg}-\mathrm{PM}_{2.5}\end{array}$ & $\begin{array}{r}50 \mathrm{~km} \\
\mathrm{Hg}-\mathrm{PM}_{2.5}\end{array}$ & $\begin{array}{r}100 \mathrm{~km} \\
\mathrm{Hg}-\mathrm{PM}_{2.5}\end{array}$ \\
\hline$n$ & 18188 & 18360 & 19794 & 1630 & 1611 & 1683 & 1631 & 1610 & 1685 \\
Min & $<\mathrm{dl}$ & $<\mathrm{dl}$ & $<\mathrm{dl}$ & $<\mathrm{dl}$ & $<\mathrm{dl}$ & $<\mathrm{dl}$ & $<\mathrm{dl}$ & $<\mathrm{dl}$ & $<\mathrm{dl}$ \\
Max & 5.24 & 7.45 & 4.73 & 36.2 & 28.1 & 87.5 & 139 & 58.7 & 201 \\
Median & 1.30 & 1.29 & 1.41 & 0.57 & 0.76 & 0.64 & 5.0 & 2.6 & 3.6 \\
Psuedo $\sigma$ & 0.16 & 0.19 & 0.20 & 0.93 & 0.85 & 0.98 & 3.9 & 2.3 & 3.0 \\
\% nd & $2 \%$ & $2 \%$ & $3 \%$ & $83 \%$ & $81 \%$ & $80 \%$ & $21 \%$ & $41 \%$ & $32 \%$ \\
\hline
\end{tabular}

$\%$ nd $=$ percent of samples below method detection limits.
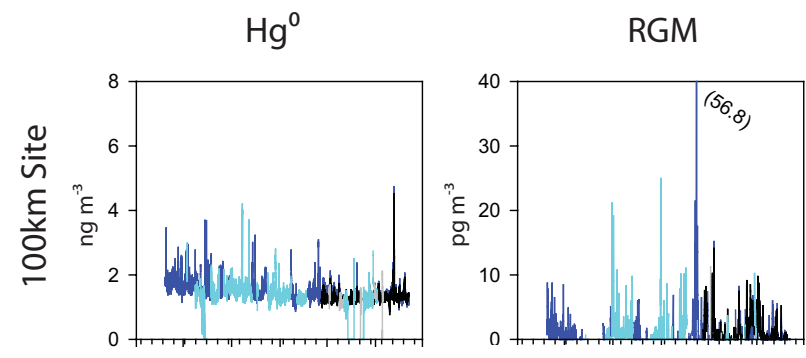

$\mathrm{Hg}_{\mathrm{PM}} 2.5$
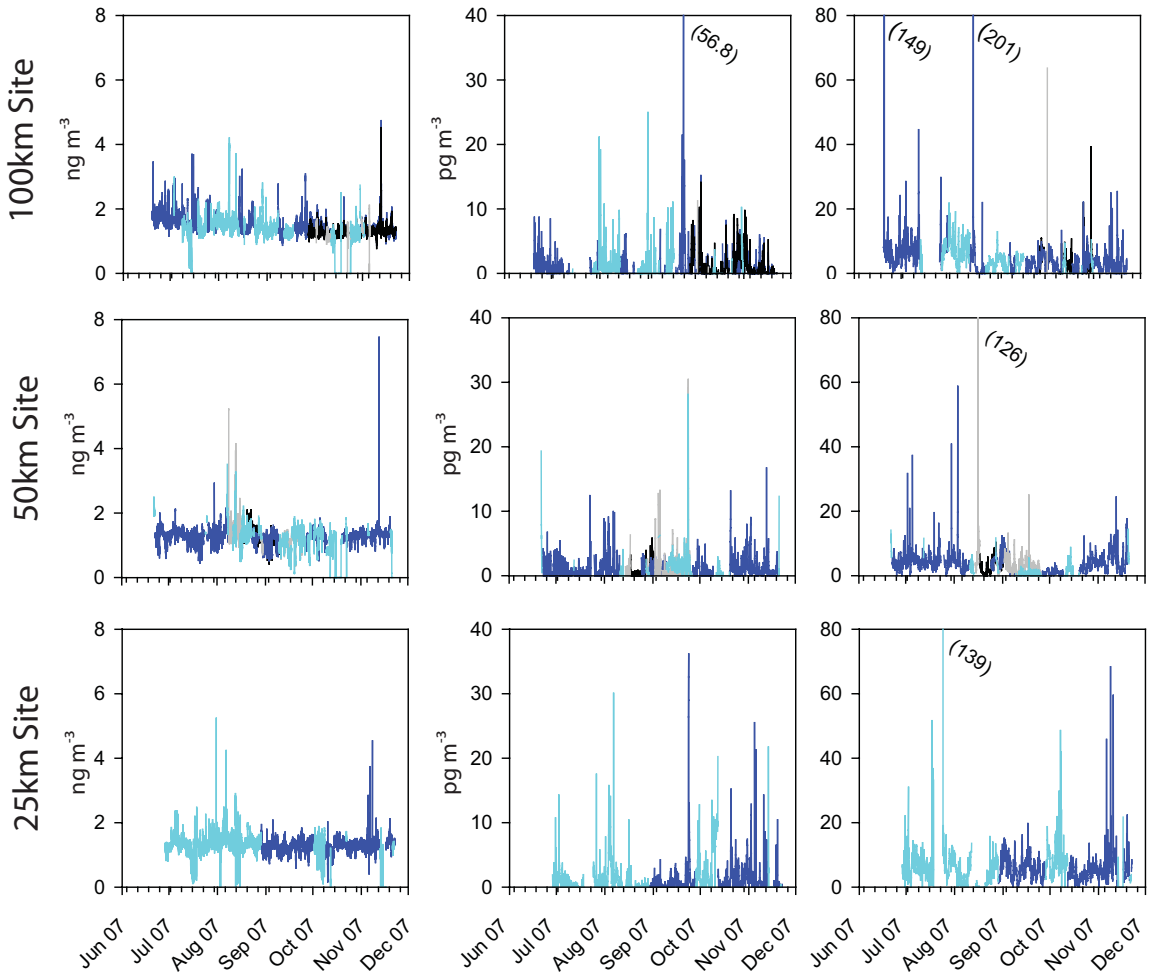

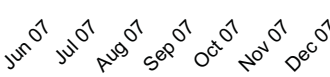

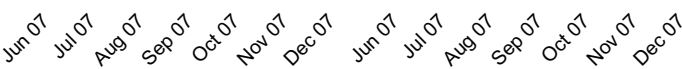

\begin{tabular}{|ll|}
\hline — Fixed Tekran, No QA Flags & - Alternate Tekran, No QA Flags \\
— Fixed Tekran, QA Flagged & Alternate Tekran, QA Flagged \\
\hline
\end{tabular}

Fig. 2. Plot of cumulative mercury speciation system output for $\mathrm{Hg}^{\circ}$ in $\mathrm{ng} \mathrm{m}^{-3}$ (left), $\mathrm{RGM}$ in $\mathrm{pg} \mathrm{m}^{-3}$ (center) and $\mathrm{Hg}_{-} \mathrm{PM}_{2.5}$ in $\mathrm{pg} \mathrm{m}^{-3}$ (right) for the $25 \mathrm{~km}$ site (bottom row), $50 \mathrm{~km}$ site (middle row), and $100 \mathrm{~km}$ site (top row). Results were collected in duplicate for the $50 \mathrm{~km}$ site (8 August to 25 September) and the $100 \mathrm{~km}$ site (27 September to 22 November).

The large RGM peak detected at each site on 23 September is reflected in a much lesser increase in $\mathrm{Hg}^{\circ} ; \mathrm{SO}_{2}$ and $\mathrm{NO}_{\mathrm{x}}$ concentrations measured at the $50 \mathrm{~km}$ site were also elevated. Transient, correlated $\mathrm{RGM}-\mathrm{SO}_{2}$ peaks at nearbaseline $\mathrm{Hg}^{\circ}$ or $\mathrm{Hg}-\mathrm{PM}_{2.5}$ are noted by Manolopoulos et al. (2007; Devil's Lake, Wisconsin, USA) and Kolker et al. (2008; Shenandoah National Park, Virginia, USA), for study areas that are largely rural and lack anthropogenic emission sources. This combination is characteristic of plumes from coal-fired generating stations (e.g. Edgerton et 

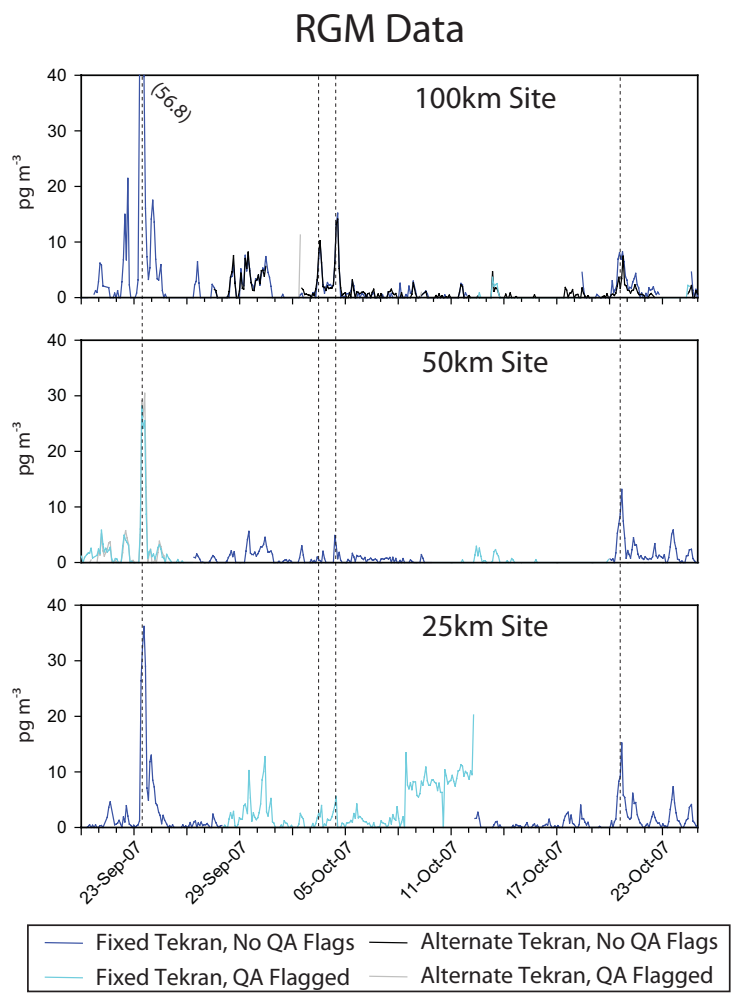

Fig. 3. Mercury speciation for mid-September through October, 2007 showing peak RGM exceeding $50 \mathrm{pg} \mathrm{m}^{-3}$ at the $100 \mathrm{~km}$ site occurring at 09:35 GMT-06:00 on 23 September, and smaller corresponding RGM peak heights at the $25 \mathrm{~km}$ site $\left(36.2 \mathrm{pg} \mathrm{m}^{-3}\right)$ and the $50 \mathrm{~km}$ site $\left(28.1 \mathrm{pg} \mathrm{m}^{-3}\right.$, qualified). The $100 \mathrm{~km}$ site is the farthest downwind at this time and date. Results for 4 and 5 October 2007 show a pattern similar to 23 September, with the largest RGM peaks recorded at the $100 \mathrm{~km}$ site, whereas results for 20 October are consistent with falloff of RGM with distance transported (see text).

al., 2006). On 23 September, all three sites were downwind of the $1114 \mathrm{MW}$ utility. However, during the 23 September RGM event, a larger RGM peak $\left(56.8 \mathrm{pg} \mathrm{m}^{-3}\right.$ ) was found at the $100 \mathrm{~km}$ site than at the $25 \mathrm{~km}$ site $\left(36.2 \mathrm{pg} \mathrm{m}^{-3}\right)$ or a qualified peak at the $50 \mathrm{~km}$ site $\left(28.1 \mathrm{pg} \mathrm{m}^{-3}\right.$; Fig. 3). Corresponding $\mathrm{Hg}^{\circ}$ is also somewhat elevated at the $100 \mathrm{~km}$ site $\left(1.76 \mathrm{ng} \mathrm{m}^{-3}\right)$ relative to the 25 and $50 \mathrm{~km}$ sites $(1.53$ and $1.56 \mathrm{ng} \mathrm{m}^{-3}$, respectively). Although ground-level winds on 23 September reflect transport from the south, the data series shows that first arrival and peak response for RGM on this date occurred at the $100 \mathrm{~km}$ site. At the other two sites, closer to the inferred source, arrival times for peak RGM were approximately coincident, with corresponding peak RGM and $\mathrm{SO}_{2}$ at the $50 \mathrm{~km}$ site (Table 2). In addition, the ratio of $\mathrm{RGM} / \mathrm{Hg}^{\circ}$, which would be expected to decrease with transport and conversion of RGM to $\mathrm{Hg}^{\circ}$ from a single source, shows a reverse trend on 23 September, with a lower value at the $25 \mathrm{~km}$ site $(0.015$ expressed as a weighted ratio for the entire event) than at the $100 \mathrm{~km}$ site $(0.020)$.
A pattern similar to that of 23 September is seen on 3 and 4 October, where peak RGM values at the $100 \mathrm{~km}$ site (9.9 and $15.2 \mathrm{pg} \mathrm{m}^{-3}$, respectively) exceed smaller $\left(\leq \sim 5 \mathrm{pg} \mathrm{m}^{-3}\right.$ ) corresponding peaks at the 25 and $50 \mathrm{~km}$ sites, under southerly wind conditions (Fig. 3). In at least one other case (20 October) peak RGM does show a regular concentration decrease from the $25 \mathrm{~km}$ site $\left(15.2 \mathrm{pg} \mathrm{m}^{-3}\right)$ to the $50 \mathrm{~km}$ site $\left(13.2 \mathrm{pg} \mathrm{m}^{-3}\right)$ to the $100 \mathrm{~km}$ site $\left(8.2 \mathrm{pg} \mathrm{m}^{-3}\right)$, and a corresponding decrease in event-weighted $\mathrm{RGM} / \mathrm{Hg}^{\circ}$, from 0.005 to 0.004 , where the $100 \mathrm{~km}$ site is the farthest downwind (Fig. 3). Results for Oct. 20 may reflect conversion of $\mathrm{RGM}$ to $\mathrm{Hg}^{\circ}$ with progressive transport, as predicted. Nonetheless, the finding that RGM is not always highest at the $25 \mathrm{~km}$ site, closest the $1114 \mathrm{MW}$ utility, could be explained if: 1) another RGM source, such as the chlor-alkali plant, or more distal regional sources, contributed to $\mathrm{Hg}$ speciation at the $100 \mathrm{~km}$ site; 2) $\mathrm{Hg}$ from the $1114 \mathrm{MW}$ utility is carried over the $25 \mathrm{~km}$ site at a high altitude as a result of its stack design parameters; or 3) RGM was being generated within the plume through oxidation of $\mathrm{Hg}^{\circ}$. Because the mercury cell chlor-alkali plant is a such a large emitter, it may be a significant RGM source, even though this process generates predominantly $\mathrm{Hg}^{\circ}$ (Southworth et al., 2004; Landis et al., 2004) with small fractions of RGM present (Landis et al., 2004).

$\mathrm{Hg}-\mathrm{PM}_{2.5}$ baseline values are generally less than $10 \mathrm{pg} \mathrm{m}^{-3}$ (Fig. 2) with more frequent excursions $\geq 20$ $25 \mathrm{pg} \mathrm{m}^{-3}$, and some values in excess of $100 \mathrm{pg} \mathrm{m}^{-\overline{3}}$ (on 20 June, 24 July, and 16 August). For the period of intensive $\mathrm{PM}_{2.5}$ sampling, time-averaged $\mathrm{Hg}-\mathrm{PM}_{2.5}$ concentrations (by automated speciation system) for the three sampling sites are similar, with median values ranging from 10.8$11.8 \mathrm{pg} \mathrm{m}^{-3}$ (see the following section).

\subsection{Intensive $\mathbf{H g}-\mathbf{P M}_{2.5}$ sampling}

Intensive PM sampling occurred from 25 July to 5 August, 2007, and included manual $\mathrm{Hg}$-TSP at all three sites and manual $\mathrm{Hg}-\mathrm{PM}_{2.5}$ at the 25 and $50 \mathrm{~km}$ sites, determined at 12-h intervals, in addition to the continued $\mathrm{Hg}-\mathrm{PM}_{2.5}$ output of the speciation systems at each site (Fig. 4). A washout event that occurred on 27 July, 2007 is seen as an Hg-TSP or $\mathrm{Hg}-\mathrm{PM}_{2.5}$ minimum at all sites. Comparison of the manual $\mathrm{Hg}$-TSP with the summed 12-h speciation system $\mathrm{Hg}$ $\mathrm{PM}_{2.5}$ output intervals shows that in virtually all cases, the manual Hg-TSP equals or is greater than the automated $\mathrm{Hg}$ $\mathrm{PM}_{2.5}$ output, showing that coarse particulate $\mathrm{Hg}$ may be present and is missed by the automated analyzers as a result of their $2.5 \mu \mathrm{m}$ input limitation (Fig. 4). Similar results have been found in previous direct comparisons between these approaches, especially where a large fraction of particulate $\mathrm{Hg}$ resides in the $\geq \mathrm{PM}_{2.5}$ fraction (Engle et al., 2008). 
Table 2. RGM and $\mathrm{SO}_{2}$ peak arrival time for 23 September 2007, showing simultaneous arrival of these maxima at the $50 \mathrm{~km}$ site and first arrival of peak RGM at the $100 \mathrm{~km}$ site.

\begin{tabular}{lcccc}
\hline 9/23/07 & $\begin{array}{c}\text { Time } \\
(\mathrm{GMT}-06: 00)\end{array}$ & $\begin{array}{c}\text { Max. pk. ht. } \\
\left(\mathrm{pg} \mathrm{m}^{-3}\right)\end{array}$ & $\begin{array}{c}\text { Time } \\
(\mathrm{GMT}-06: 00)\end{array}$ & $\begin{array}{c}\text { Max. pk. ht. } \\
(\mathrm{ppbv})\end{array}$ \\
\hline $25 \mathrm{~km}$ & $13: 35$ & 36.2 & NA & NA \\
$50 \mathrm{~km}$ & $10: 35$ & $28.1^{*}$ & $10: 30$ & 10.4 \\
$100 \mathrm{~km}$ & $09: 35$ & 56.8 & NA & NA \\
\hline
\end{tabular}

* Qualified value.
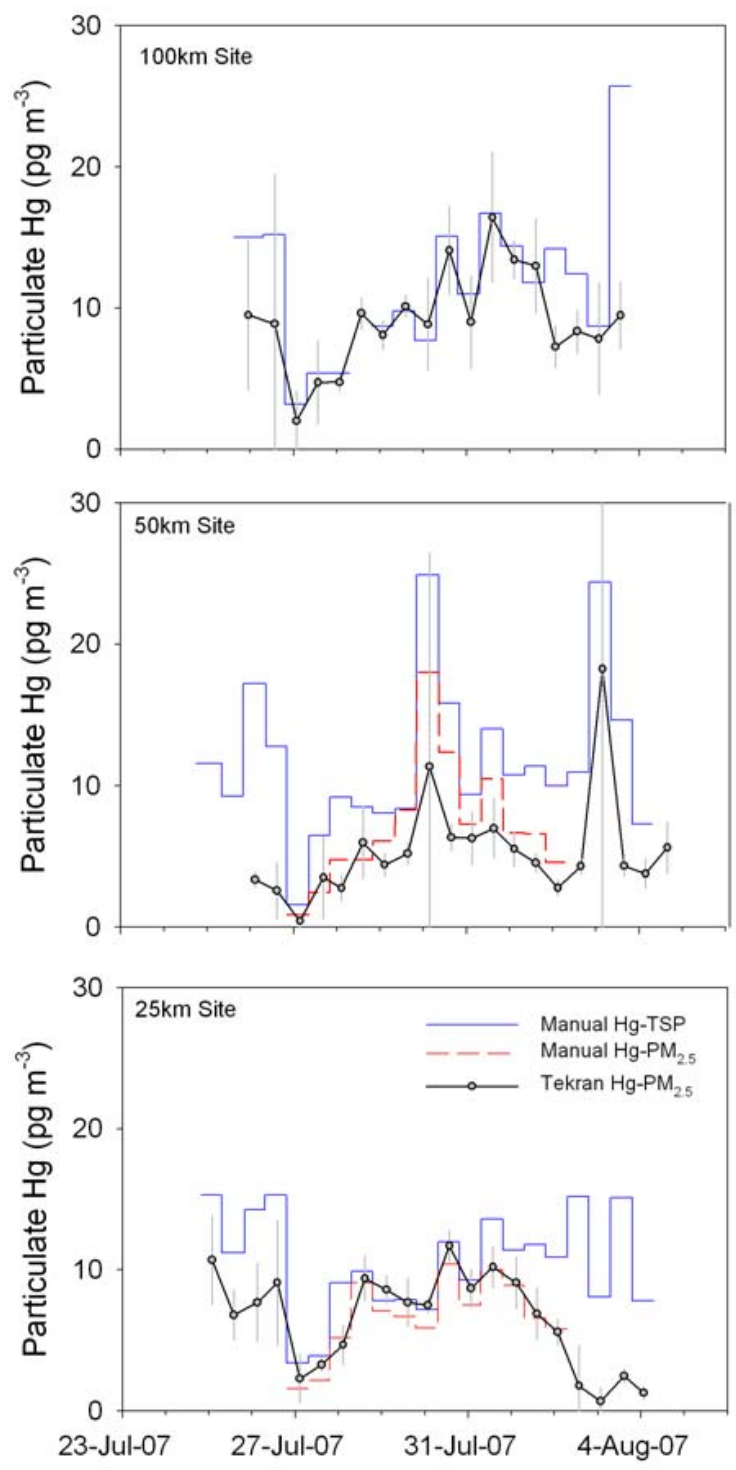

Fig. 4. Comparison of 12-h manual Hg-TSP vs. summed 12-h speciation system $\mathrm{Hg}-\mathrm{PM}_{2.5}(25,50,100 \mathrm{~km}$ sites) and 12-h manual $\mathrm{Hg}$-TSP $\left(25,50 \mathrm{~km}\right.$ sites only), for the period of intensive $\mathrm{Hg}-\mathrm{PM}_{2.5}$ sampling, 25 July-5 August, 2007.

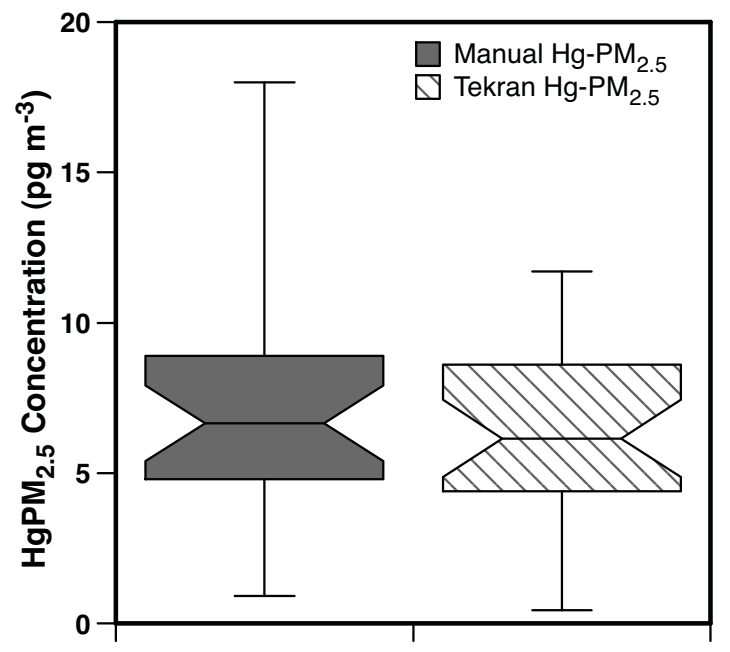

Fig. 5. Boxplot showing overlap in concentration ranges for 12-h manual $\mathrm{Hg}-\mathrm{PM}_{2.5}$ vs. summed 12-h speciation system $\mathrm{Hg}-\mathrm{PM}_{2.5}$ sampling, 25 July-5 August, 2007.

Where manually determined, 12-h Hg-PM 2.5 concentrations were compared with summed 12-h speciation system $\mathrm{Hg}-\mathrm{PM}_{2.5}$ (at the 25 and $50 \mathrm{~km}$ sites); the results show no statistically significant difference in the two approaches (Fig. 5), with a regression comparison biased slightly to the manual approach, giving a slope of 0.84 and an $r^{2}$ of 0.55 . Consistency between the manual and automated approaches for $\mathrm{Hg}$ $\mathrm{PM}_{2.5}$ indicates that comparison between $\mathrm{Hg}$-TSP and speciation system $\mathrm{Hg}-\mathrm{PM}_{2.5}$ discussed above is valid because the filter-based approach used has not been subject to artifacts resulting from adherence or loss of gaseous mercury to or from the filter media (e.g. Malcolm and Keeler, 2007).

\subsection{Directional mercury and ancillary gas concentration data}

Directional patterns of mercury and ancillary gas distribution for the period from June to November, 2007 are shown by concentration roses for $\mathrm{RGM}, \mathrm{Hg}^{\circ}$, and $\mathrm{Hg}-\mathrm{PM}_{2.5}$ for each site, and $\mathrm{SO}_{2}$ and $\mathrm{NO}_{\mathrm{x}}$ roses for the $50 \mathrm{~km}$ site (Fig. 6). 


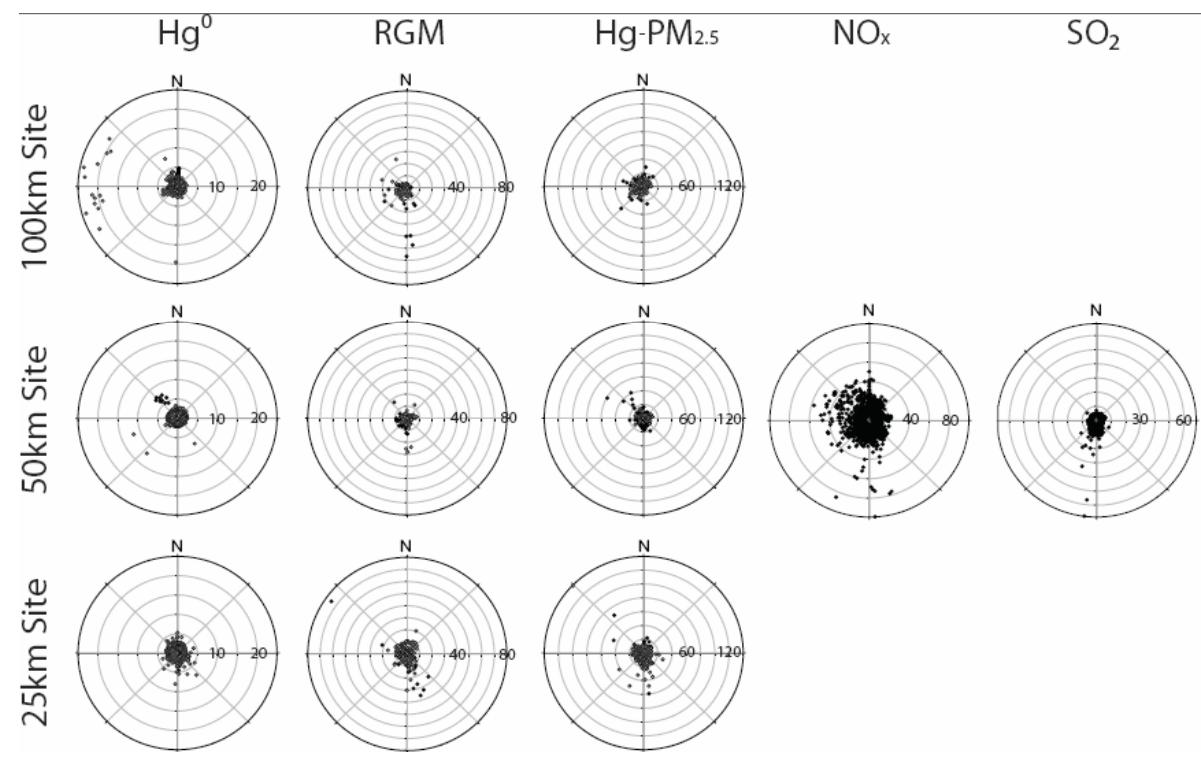

Fig. 6. Rose diagrams for mercury species $(25,50,100 \mathrm{~km}$ sites $)$ and ancillary gases (50 km site).

For RGM, the highest events recorded $\left(\geq 30 \mathrm{pg} \mathrm{m}^{-3}\right)$ are at the $100 \mathrm{~km}$ site, with the prevailing wind from the south, the direction of the $1114 \mathrm{MW}$ power station. At this site, lesser RGM highs are seen with winds from the WSW, the direction of the chlor-alkali plant, from the NNW, the direction of the $465 \mathrm{MW}$ coal burning utility, and from the $\mathrm{SE}$, in the direction of more distal power plant sources in the urbanized corridor along the shores of Lake Michigan, near the Illinois/Wisconsin border. At the $25 \mathrm{~km}$ site, RGM highs occur with southeast winds, towards these regional emission sources, in addition to highs occurring under due-south winds, towards the $1114 \mathrm{MW}$ power station. The due-south RGM highs at the $25 \mathrm{~km}$ site are less pronounced than at the $100 \mathrm{~km}$ site, even though the $25 \mathrm{~km}$ site is closer to this emitter.

For $\mathrm{Hg}^{\circ}$, the most pronounced directional highs $\left(\geq 3 \mathrm{ng} \mathrm{m}^{-3}\right)$ are at the $50 \mathrm{~km}$ site, when winds are from the northwest, towards the chlor-alkali plant. For $\mathrm{Hg}-\mathrm{PM}_{2.5}$, highs $\left(\geq 20 \mathrm{pg} \mathrm{m}^{-3}\right)$ occur at the $25 \mathrm{~km}$ site with winds from the south, towards the $1114 \mathrm{MW}$ power station; at the $50 \mathrm{~km}$ site with winds from the NW, towards the chlor-alkali plant; and at the $100 \mathrm{~km}$ site with winds from the WSW, also the direction of the chlor-alkali plant (Fig. 6). Similar rose-diagram treatment of $\mathrm{SO}_{2}$ and $\mathrm{NO}_{\mathrm{x}}$ data for the $50 \mathrm{~km}$ site shows considerable scatter, with the most pronounced directional trend being towards the south (1114 MW utility) for each ancillary gas. For the pronounced $\mathrm{Hg}^{\circ}$ high at the $50 \mathrm{~km}$ site with winds from the northwest, the lack of a corresponding $\mathrm{SO}_{2}$ high is consistent with influence by the chlor-alkali plant, as suggested above.

Comparison of cumulative RGM results for the three sites as a function of wind direction is shown in Fig. 7. When winds are from the south $\left(170\right.$ to $190^{\circ}$; Fig. 7a), of the three
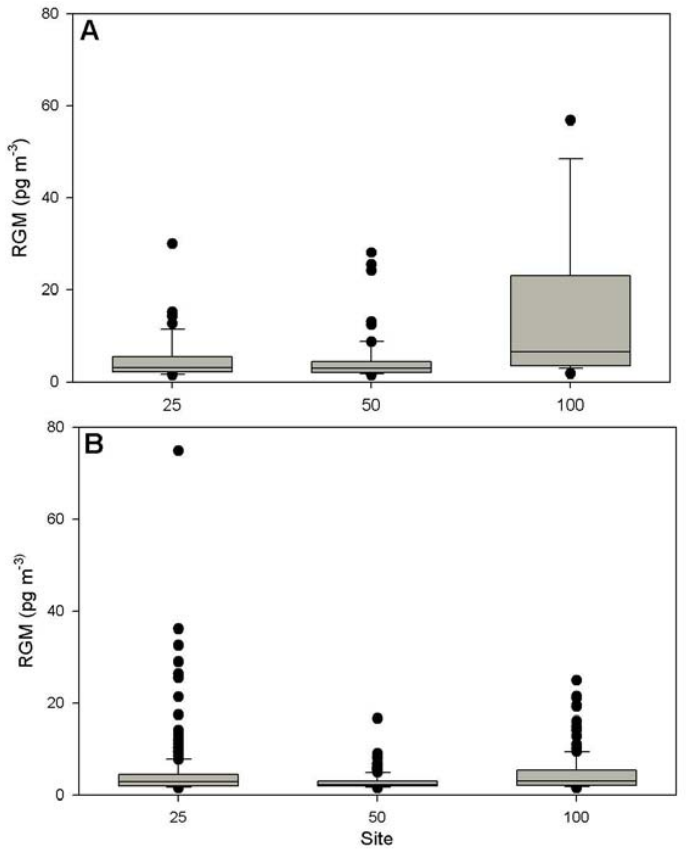

Fig. 7. Boxplots showing RGM results $\left(\geq 1.5 \mathrm{pg} \mathrm{m}^{-3}\right)$ for each site when winds are from the south (170-190; top panel A) and from all other directions (190-170; bottom panel B). Results do not show a consistent decrease in RGM concentration with distance from the large emission source due south of the $25 \mathrm{~km}$ site.

sites, the $100 \mathrm{~km}$ site consistently shows the highest RGM values, whereas RGM values for the other two sites are indistinguishable. When winds are from all other directions (190 to $170^{\circ}$; Fig. $7 b$ ), RGM values for all three sites are indistinguishable. This finding is counter to conventional 
thinking and assumptions applied to $\mathrm{Hg}$ transport modeling suggesting a mercury dispersion "halo" exists around large emission sources, whereby RGM is expected to decrease with distance from a central high as a function of dispersion and conversion to $\mathrm{Hg}^{\circ}$ (Bullock et al., 1998; Cohen et al., 2004; Lee and Keener, 2008).

\subsection{Air-mass back trajectories}

Mercury speciation data, ancillary gas data, and directional information discussed above show that local emission sources at the periphery of the study area result in periodic elevation of RGM, $\mathrm{Hg}^{\circ}$ and, for transient plumes from coalburning utilities, correlated RGM and $\mathrm{SO}_{2}$. The contribution of regional sources is more difficult to assess without knowing the back-trajectory of air-masses being sampled in the study area. Using the NOAA HYSPLIT model (Draxler and Rolph, 2003), backward air mass trajectories were simulated for the 23 September, 4 October, and 20 October, 2007 events, in which RGM peaks occurred under the influence of southern winds. Results show significant variation in source areas depending on the ending height of the trajectory (i.e., $10 \mathrm{~m}, 500 \mathrm{~m}, 1000 \mathrm{~m}$; Fig. 8). Given that all peaks investigated occurred during daytime, significant mixing was likely occurring in the boundary layer and variations in contributions from the various source areas likely occurred between the three sampling sites. For example, trajectories corresponding to the RGM pulse on 23 September, 2007 ending at heights of 100 and $500 \mathrm{~m}$, originated near Chicago, a significant regional source area for atmospheric $\mathrm{Hg}$, and were modeled to have been transported near the coal-fired utility power station due south of the receptor sites (Fig. 8). These findings suggest that contributions from multiple sources may have been responsible for elevated RGM concentration during this and other events, and this may help explain the unexpected first arrival of the source plume at the furthest monitoring site.

\section{Conclusions}

Three simultaneously operated atmospheric mercury sites in rural Central Wisconsin show sporadic elevation of RGM, $\mathrm{Hg}^{\circ}$ and $\mathrm{Hg}-\mathrm{PM}_{2.5}$. Correspondence of elevated $\mathrm{Hg}$ species varies between sites; correspondence between elevated mercury species and ancillary gas levels is similarly variable. These variations are likely the result of differing contributions of local- to regional scale emission sources and variation in air mass transport direction. Some RGM peaks have associated $\mathrm{SO}_{2}$ peaks, together indicative of plumes from coal burning utility power stations, whereas others do not, indicating they are more likely derived from the mercury-bed chlor-alkali facility. The greatest peak response concentrations were commonly observed at the $100 \mathrm{~km}$ site, farthest from the largest power plant $\mathrm{Hg}$ emission source. This sug-

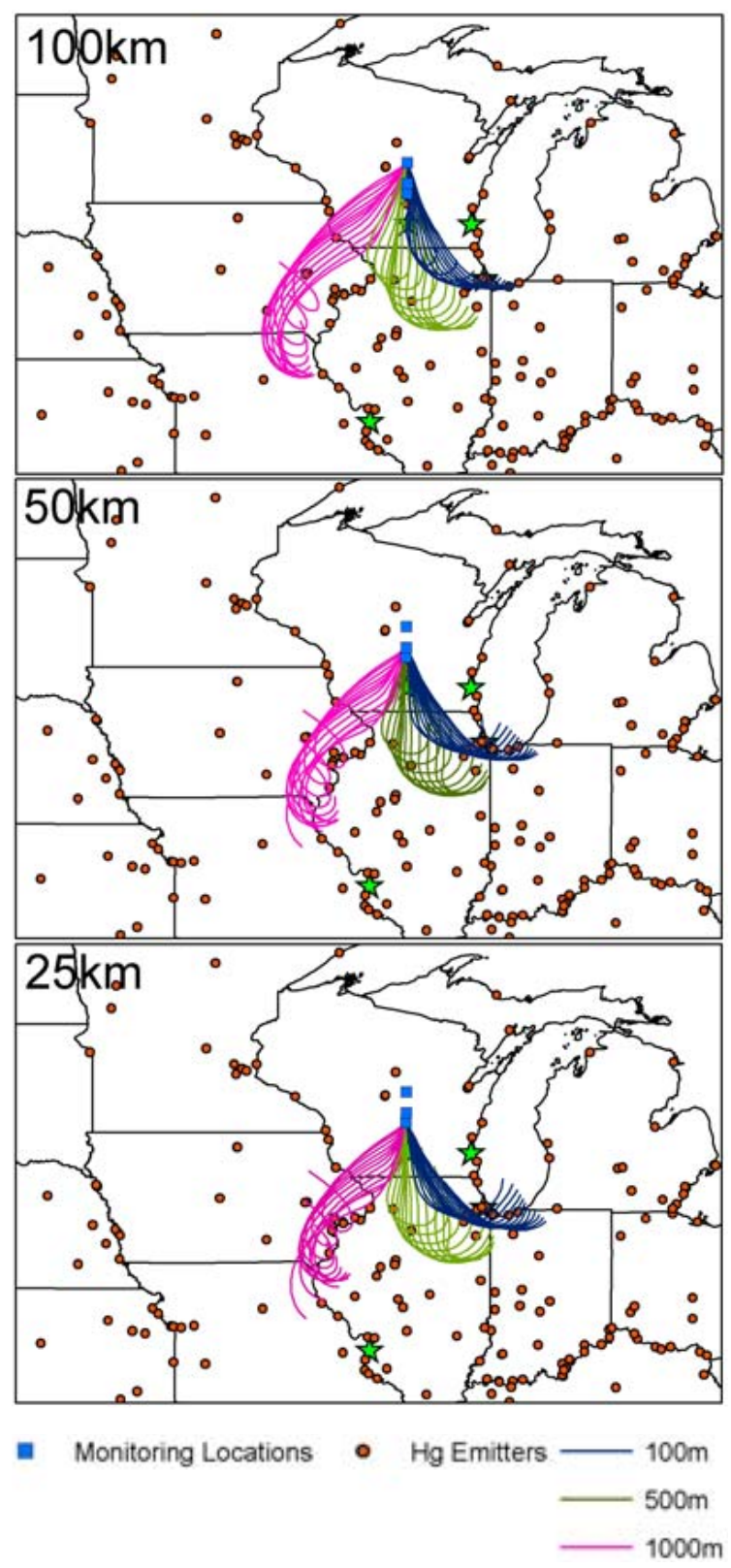

Fig. 8. NOAA HYSPLIT multiple 24-h air mass back trajectory model results for 23 September 2007. $24 \mathrm{~h}$ back trajectories begin each hour from 09:00 to 15:00 local time, the period of elevated RGM at each station. Results show variation in source area as a function of air mass height. This plot suggests that multiple source areas contribute to each $\mathrm{Hg}$ event observed.

gests that the $100 \mathrm{~km}$ site is most-likely impacted by other $\mathrm{Hg}$ sources, in addition to the $1114 \mathrm{MW}$ power station to the south. Overall, highest RGM concentrations occur with air masses from the south (all sites) or the northwest $(25,50 \mathrm{~km}$ sites), or west-southwest (100 km site), downwind of the two largest mercury sources. Short-term manual replication of Hg-PM 2.5 shows good agreement with automated $\mathrm{Hg}-\mathrm{PM}_{2.5}$ 
measurements, thereby validating the filter-based collection method. Manual Hg-TSP determination indicates that significant fractions of particulate mercury may be coarser than the $2.5 \mu \mathrm{m}$ orifice limitation of the automated speciation systems. HYSPLIT air mass back-trajectories are helpful in assessing the contribution of mercury from regional sources such as major cities, and in showing divergence in transport at differing levels of the atmosphere. This approach is not useful in distinguishing among the local sources at the periphery of the study area, because the back-trajectory grid-size $(40 \mathrm{~km})$ is too coarsely spaced. Operational changes to the local emission sources make it impossible to replicate conditions of the study, but these changes have the overall effect of reducing mercury emissions in the study area.

Acknowledgements. This study was supported by an interagency agreement (\#DW-14-922332-01) between the USGS and the US EPA Office of Air and Radiation, Clean Air Markets Division. Field work by Engle and Kolker was supported by the US Geological Survey Toxic Substances Hydrology (Toxics) Program, and the USGS Energy Resources Program. We acknowledge support of the USGS Toxics Program for participation (by Kolker) in the 9th International Conference on Mercury as a Global Pollutant, where an earlier version of this paper was presented. We thank Casey Soneira and John DeWild for assistance in the field and Nicholas Geboy for help in preparation of figures. The comments of two anonymous ACPD reviewers helped improve the manuscript. Use of trade, product, or firm names is for descriptive purposes only and does not imply endorsement by the US Government.

Edited by: K.-H. Kim

\section{References}

Banic, C., Blanchard, P., Dastoor, A., Hung, H., Steffen, A., Tordon, R., Poissant, L., and Wiens, B.: Atmospheric distribution and long-range mercury transport, in: Mercury: Sources, measurements, cycles, and effects, Parsons, M.B. and Percival, J.B. (Eds.), Mineralogical Association of Canada, Short Course Series, 34, 157-177, 2005.

Bragg, L. J., Oman, J. K., Tewalt, S. J., Oman, C. L., Rega, N. H., Washington, P. M., and Finkelman, R. B.: U.S. Geological Survey Coal Quality (COALQUAL) Database: Version 2.0, U.S. Geological Survey Open File Report 97-134, CD-ROM, 1998.

Bullock, O. R., Brehme,K. A., and Mapp, G. R.: Lagrangian modeling of mercury air emission, transport and deposition: An analysis of model sensitivity to emissions uncertainty, Sci. Total Environ., 213(1-3), 1-12, 1998.

Campbell, T., Gertz, F. X, Mataczynski, K., Amrhein, G. T., Filippelli, G., and Stewart, R.: Mercury control optimization study at Wisconsin Public Service Weston Unit 4, in: Proceedings, Air Quality VII, Arlington, VA, October, 2009, 12, 2009.

Cohen, M., Artz, R., Draxler, R., Miller, P., Poissant, L., Niemi, D., Ratté, D., Deslauriers, M., Duval, R., Laurin, R., Slotnick, J., Nettesheim, T., and McDonald, J.: Modeling the atmospheric transport and deposition of mercury to the Great Lakes, Environ. Res., 95(3), 247-265, 2004.
Draxler, R. R. and Rolph, G. D.: HYSPLIT (HYbrid Single-Particle Lagrangian Integrated Trajectory) Model access via NOAA ARL READY Website (http://www.arl.noaa.gov/ HYSPLIT.php), NOAA Air Resources Laboratory, Silver Spring, MD, 2003.

Edgerton, E. S., Hartsell, B. E., and Jansen, J. J.: Mercury speciation in coal-fired power plant plumes observed at three surface sites in the southeastern U.S., Environ. Sci. Technol., 40, 45634570, 2006.

Electric Energy Online: Emission control projects completed at Weston power plant, http://www.electricenergyonline.com/?page= show_news $\backslash \&$ id=109588(last access: 6 January 2010), 17 April 2009.

Engle, M. A., Tate, M. T., Krabbenhoft, D. P., Kolker, Allan, Olson, M. L., Edgerton, E. S., DeWild, J. F., and McPherson, A. $\mathrm{K}$.:Characterization and cycling of atmospheric mercury along the central U.S. Gulf Coast, Appl. Geochem., 23, 419-437, doi:1016/j.apgeochem.2007.12.024, 2008.

Hawthorne, Michael, Big polluter to cut mercury, Chicago Tribune, online available at: http://www.chicagotribune.com/news/ nationworld/chi-mercury13aug13,0,7040214.story(last access: 6 January 2010), 13 August 2007.

Hooyer, T. S.: Landscapes of Wisconsin: Madison, Wisconsin Geological and Natural History Survey, 1:500 000, 2001.

Kolker, A., Senior, C. L., and Quick, J. C.: Mercury in coal and the impact of coal quality on mercury emissions from combustion systems, Appl. Geochem., 21, 1821-1836, 2006.

Kolker, A., Engle, M. A., Krabbenhoft, D. P., and Olson, M. L.: Investigating atmospheric mercury with the USGS Mobile Mercury Laboratory, USGS Fact Sheet FS 2007-3071, 4 pp., 2007.

Kolker, A., Engle, M. A., Orem, W. H., Bunnell, J. E., Lerch, H. E., Krabbenhoft, D. P., Olson, M. L., DeWild, J. F., and McCord, J. D.:Mercury, trace elements, and organic constituents in atmospheric fine particulate matter, Shenandoah National Park, Virginia, USA: A combined approach to sampling and analysis, Geostand. Geoanal. Res., 32, 279-293, 2008.

Landis, M., Stevens, R., Schaedlich, F., and Prestbo, E.: Development and characterization of an annular denuder methodology for the measurement of divalent inorganic reactive gaseous mercury in ambient air, Environ. Sci. Technol., 36, 3000-3009, 2002.

Landis, M. S., Keller, G. J., Al-Wali, K. I., and Stevens, R. K.: Divalent inorganic reactive gaseous mercury emissions from a mercury cell chlor-alkali plant and its impact on near-field atmospheric dry deposition, Atmos. Environ., 38, 613-622, 2004.

Lee, S. and Keener, T. C.: Dispersion modeling of mercury emissions from coal-fired power plants at Coshocton and Manchester, Ohio, Ohio J. Sci., 108(4), 65-69, 2008.

Malcolm, E. G. and Keeler, G. J.: Evidence for a sampling artifact for particulate-phase mercury in the marine atmosphere, Atmos. Environ., 41, 3352-3359, 2007.

Manolopoulos, H., Schauer, J. J., Purcell, M. D., Rudolph, T. M., Olson, M. L., Rodger, B., and Krabbenhoft, D. P.: Local and regional factors affecting atmospheric mercury speciation at a remote location, J. Environ. Eng. Sci., 6, 491-501, 2007.

Olund, S. D., DeWild, J. F., Olson, M. L., and Tate, M. T.: Methods for the preparation and analysis of solids and suspended solids for total mercury, in: Laboratory Analysis, Book 5, Section A, Water Analysis, US Geological Survey, 23, 2004. 
Peltier, R.: Wisconsin Public Service Corp.'s Weston 4 earns POWER's highest honor, Power Magazine, 5 pp., online available at: http://www.powermag.com/coal/ Wisconsin-Public-Service-Corp-s-Weston-4-earns-POWERs $\{-\}$ highest-honor_1384.html (last access: 6 January 2010), 15 August 2008 .

Southworth, G. R., Lindberg, S. E., Zhang, H., and Anscombe, F. R.: Fugitive mercury emissions from a chlor-alkali factory: Sources and fluxes to the atmosphere, Atmos. Environ., 38, 597611, 2004.

Tewalt, S. J., Bragg, L. J., and Finkelman, R. B.: Mercury in U.S. coal-Abundance, distribution, and modes of occurrence, US Geological Survey Fact Sheet FS-095-01, 4 pp., 2001.
US Environmental Protection Agency (EPA): 2006 Toxics Release Inventory (TRI) State Data Files (Wisconsin), online available at: http://epa.gov/tri/tridata/tri06/data/index.htm\#h4 (last access: 16 November 2009), 2008.

Wiener, J. G., Krabbenhoft, D. P., Heinz, G. H., and Scheuhammer, A. M.: Ecotoxicology of mercury, Chap. 16, in: Handbook of Ecotoxicology, 2nd edn., edited by: Hoffman, D. J., Rattner, B. A., Burton Jr., G. A., and Cairns Jr., J., CRC press, Boca Raton, Florida, USA, 407-461, 2003. 